\title{
Epigenetic variation of the common shrew, Sorex araneus, in different habitats
}

\author{
Jan M. Wójcik*, P. David Polly, Anna M. Wójcik \& Michał D. Sikorski
}

\begin{abstract}
Epigenetic variation of the common shrew, Sorex araneus, was studied in three habitats (floodplain forest, wet sedge bog and dry meadow) at Białowieża, north-eastern Poland. Previous chromosome and allozyme studies of the same population suggested that polymorphisms are related to environmental heterogeneity and that random factors influence frequencies of acrocentric chromosomes and alleles. In the present study we tested whether similar processes influence epigenetic variation. Thirty-one non-metric skull traits were scored in 274 individuals from samples collected in different biotopes. The specific aim of the study was to estimate non-metric trait frequencies and fluctuating asymmetry in shrews from different habitats, and to explain the factors involved in the maintenance of epigenetic polymorphism. Significant differences found among samples of shrews from different habitats indicated that important epigenetic variation exists within the population. This epigenetic variation in the common shrew appears to be related to environmental heterogeneity.
\end{abstract}

KEY WORDS: Sorex araneus, common shrew, epigenetic variation, environmental heterogeneity.

Jan M. Wójcik[jwojcik@bison.zbs.bialowieza.pl], Anna M. Wójcik, and Michat D. Sikorski, Mammal Research Institute, Polish Academy of Sciences, 17-230 Białowieża, Poland; P. David Polly [pdpolly@indiana.edu], Department of Geological Sciences, Indiana University, Bloomington, Indiana 47405, USA.

\section{Эпигенетическая изменчивость обыкновенной бурозубки, Sorex araneus, в различных местообитаниях}

\author{
Я.М. Вуйчик, П.Д. Полли, А.М. Вуйчик, М.Д. Сикорски
}

\begin{abstract}
РЕЗЮМЕ. ЭПигенетическая изменчивость обыкновенной бурозубки, Sorex araneus, была изучена в 3 местообитаниях (пойменный лес, осоковое болото и сухой луг) в Беловеже, северо-восточная Польша. Из предыдущих хромосомных и аллозимных исследований тех же популяций следовало, что полиморфизм связан с гетерогенностью среды обитания и что случайные факторы влияют на частоты акроцентрических хромосом и аллелей. В настоящем исследовании мы изучали, имеются ли подобные влияния на эпигенетическую изменчивость. Проанализирован 31 неметрический черепной признак у 274 экземпляров из выборок, относящихся к различным биотопам. Целью работы являлось определение частот неметрических признаков и флуктуирующей асимметрии у бурозубок из разных местообитаний и выявление факторов, участвующих в поддержании эпигенетического полиморфизма. Значимые различия, найденные между выборками бурозубок из разных местообитаний, указывают на существенную эпигенетическую изменчивость внутри популяции. Эпигенетическая изменчивость у обыкновенной бурозубки может быть связана с гетерогенностью среды.
\end{abstract}

КЛЮЧЕВЫЕ СЛОВА: Sorex araneus, обыкновенная бурозубка, эпигенетическая изменчивость, гетерогенность среды обитания.

\section{Introduction}

One method for studying genetic variation in mammal populations is to measure differences in non-metric skeletal traits, so-called epigenetic polymorphisms. These threshold traits are under the control of both genetic and non-genetic factors. If the total genetic and non-genetic effect is greater than the value corresponding to the threshold, the variant is manifested (Sjøvold, 1977; Andersen \& Wiig, 1982). Both genetic and envi-

\footnotetext{
* Corresponding author
}

ronmental factors are known to be important in controlling skeletal epigenetic traits such as the number of minor skull foramina (Berry, 1963; Berry \& Searle, 1963; Andersen \& Wiig, 1982; Pankakoski, 1985).

From non-metric traits a mean measure of genetic divergence (MMD) between the samples can be estimated for use as a genetic distance measure. MMD is one of many possible measures that can be made from non-metric traits, but it is the most intuitive and commonly used (Sjøvold, 1977).

Non-metric traits can also be used for calculation of fluctuating asymmetry (FA) and the mean number of 
asymmetrical characters per individual (NA). Fluctuating asymmetry, or differences between the two sides of the body that cannot be explained by either genetic factors, is a common index of developmental stability (Palmer \& Strobeck, 1986; Zakharov, 1992; Palmer \& Strobeck, 1992). When there is a genetic basis for variability in a trait showing FA (i.e. its broad-sense heritability is greater than zero), then FA represents a measure of the sensitivity of development to accidents (Leary \& Allendorf, 1989). Each side of an animal has the same genetic constitution, so bilateral differences are non-genetic developmental characteristics that arise through chance or environmental perturbation. It is thought that canalizing processes minimize bilateral symmetry, but when developmental stability is disrupted asymmetry becomes more common. Developmental stability can be reduced by factors such as extreme physical conditions, pollution or poor habitat quality (Palmer \& Strobeck, 1992). High developmental stability, that is low fluctuating asymmetry, is associated with coadapted genotypes under optimal environmental conditions, but deterioration in stability, and higher fluctuating asymmetry, can be expected under stressful conditions. If environmental stress during ontogeny results in greater asymmetry of various traits, then studies of morphological asymmetry can throw light on the ecological conditions of animal populations (Pankakoski, 1985).
In shrews, non-metric variation has been examined by Hanski (1986), Hanski \& Kuitunen (1986), Pankakoski \& Hanski (1989), Zakharov et al. (1991), Pankakoski et al. (1992), Meyer \& Searle (1994), Zakharov et al. (1997a, 1997b), Badyaev \& Foresman (2000, 2004) and Badyaev et al. (2000, 2005). Studies in Eurasia showed that shrew skeletal growth is highly sensitive to variation in environmental conditions (e.g. Pankakoski et al., 1992). Shrews are short-lived insectivorous mammals with a majority of their breeding occurring in a short period of time. They have a short period of skeletal growth (Foresman, 1994) and their entire lives are filled with nearly continuous prey-searching and foraging activity (Genoud, 1988). The type of non-metric cranial traits that we studied would have been formed during early skeletogenesis, probably in utero.

In the present investigation, we studied common shrews in samples from Białowieża (north-eastern Poland) and tested whether epigenetic variation is associated with environmental heterogeneity. The specific aim of the study was to analyse non-metric trait frequencies and fluctuating asymmetry in shrews from different habitats, and also an attempt to explain the factors involved in the maintenance of epigenetic polymorphism in the population. Previous studies of Sorex araneus populations from Białowieża showed mixed associations of habitat and population differentiation. Wójcik (1991) and Wójcik et

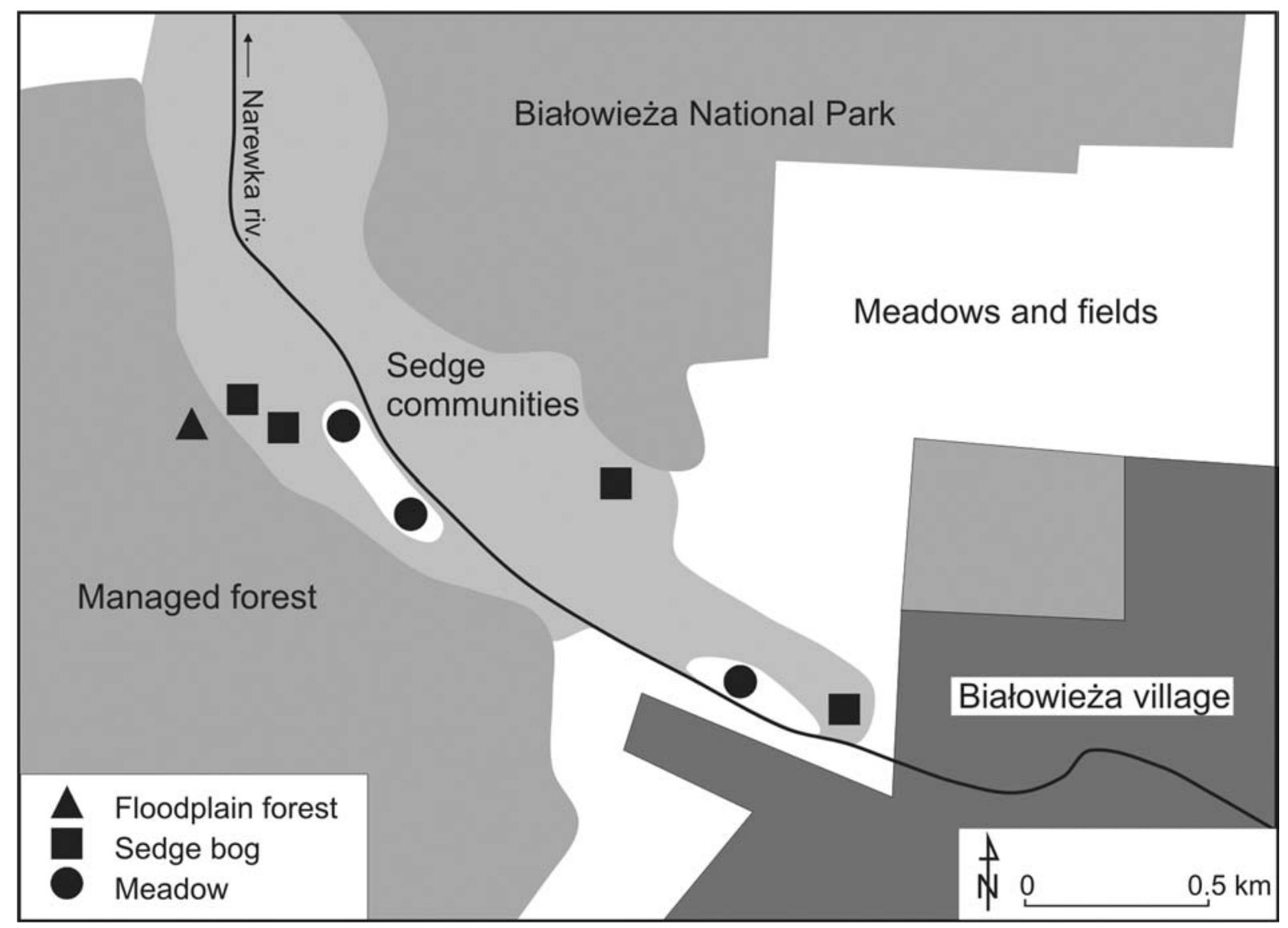

Figure 1. A schematic map of the study area. 
al. (1996) concluded that chromosome and allozyme polymorphisms were related to environmental heterogeneity; however, morphometric differentiation of mandible shape was not (Wójcik et al., 2003). Previous studies of mandibular shape in the common shrew have found the greatest differentiation at higher hierarchical levels than the population, notably among species within the $S$. araneus-arcticus group and among karyotypic groups of S. araneus (Hausser \& Jammot, 1974; Polly, 2006), whereas previous studies of epigenetic variation have found significant differentiation at the population level.

\section{Material and methods}

Samples of common shrews were collected in three distinct habitats within the Białowieża Primeval Forest, north-eastern Poland (N 52 $42^{\prime}$, E $23^{\circ} 55^{\prime}$ ): floodplain ash-alder forest (Circaeo-Alnetum), wet sedge bog and dry meadow (Fig. 1). Floodplain forest is a heterogeneous biotope with high levels of ground water year
Table 1. Material used in this study.

\begin{tabular}{|l|c|c|c|c|c|}
\hline \multirow{2}{*}{$\begin{array}{l}\text { Habitat and } \\
\text { trapping period }\end{array}$} & \multicolumn{2}{|c|}{ Males } & \multicolumn{2}{c|}{ Females } & \multirow{2}{*}{ Total } \\
\cline { 2 - 5 } & adult & young & adult & young & \\
\hline $\begin{array}{l}\text { Floodplain forest } \\
\text { 1993-1995 }\end{array}$ & 4 & 15 & 0 & 12 & 31 \\
\hline $\begin{array}{l}\text { Sedge bog } \\
\text { 1988-1995 }\end{array}$ & 20 & 75 & 14 & 82 & 191 \\
\hline $\begin{array}{l}\text { Meadow } \\
\text { 1987-1994 }\end{array}$ & 10 & 20 & 3 & 19 & 52 \\
\hline Total & 34 & 110 & 17 & 113 & 274 \\
\hline
\end{tabular}

round. Sedge bog (Carex spp.) is a homogeneous wet and open biotope. Meadow is homogeneous dry grassland biotope located on higher ground and surrounded by wet sedge bogs.

Shrews were trapped in 1987-1995. A total of 274 individuals (144 males and 130 females) belonging to the Białowieża chromosome race (see Zima et al., 1996
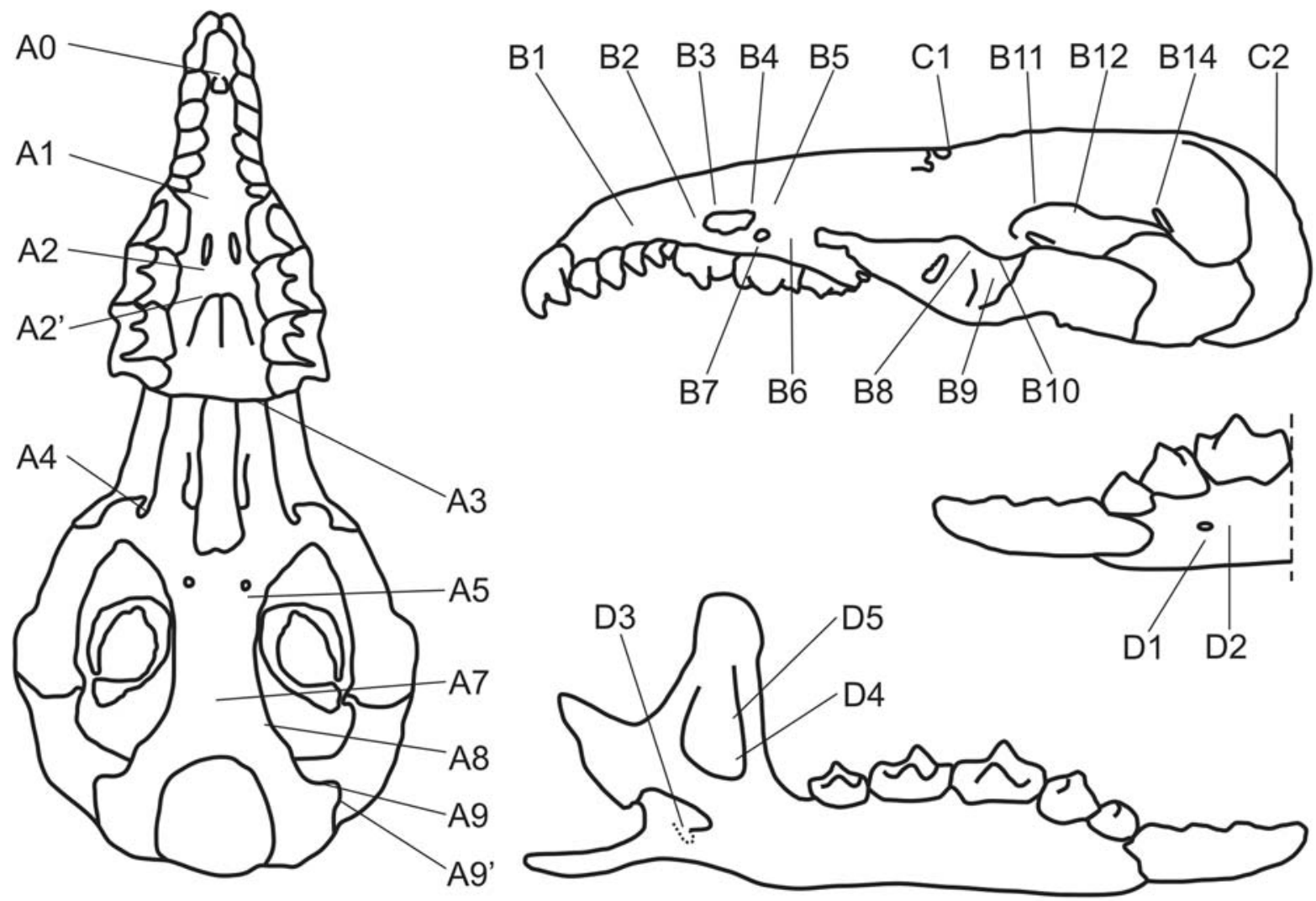

Figure 2. Non-metric traits on the skull of the common shrew used in the study.

A 0 - foramen incisivum, unilateral; A1 - medial palatine foramen; A2 - posterior palatine foramen; A2' - accessory posterior palatine foramen; A 3 - accessory terminal palatine foramen; A 4 - foramen ovale; A5 - accessory foramen posterior to the basisphenoid foramen; A7 - median basioccipital foramen, unilateral; A8 - posterior basioccipital foramen; A9 - accessory hypoglossal foramina I (1 or 2); A9' - accessory hypoglossal foramen II; B1 — premaxillary foramina; B2 - anterior maxillary foramen; B3 - accessory foramen outside infraorbital foramen; B4 - accessory foramen above the rim of infraorbital foramen; B5 - accessory foramen posterior to B4; B6 accessory foramen posterior to lacrimal foramen; B7 - accessory foramen below lacrimal foramen; B8 - accessory posterior alisphenoid foramen; B9 - pneumatic foramen between the two articular condyles; B10 — anterolateral parietal foramen; B11 — anterior lateral sinus foramen; B12 - mesial lateral sinus foramina; B14 - posterior lateral sinus foramen; C1 - parietofrontal foramen; $\mathrm{C} 2$ - median supraoccipital foramen; D1 — anterior accessory foramen to the major mental foramen; D2 - lower mental foramen; D3 — dentary canal; D4 - lower coronoid foramen; D5 - upper coronoid foramen. 
and Wójciket al., 2003) were used in this study. Thirtyone shrews were trapped in floodplain ash-alder forest, 191 in wet sedge bog, and 52 in dry meadow (Tab. 1). Most of the shrews were young (still in their first year), sexually immature animals caught between early August and November.

Skulls were cleaned by dermestid beetles (Dermestes lardarius), then digested in a papain solution and bleached in 3\% hydrogen peroxide to separate the elements for non-metric trait scoring.

Thirty-one non-metric traits (foramina for blood vessels or nerves) were scored (Fig. 2). The number of foramina in the 29 bilateral traits was used in fluctuating asymmetry analysis. Classification criteria for 29 of the traits were described by Hanski \& Kuitunen (1986). Only three of the traits were new to this paper: A0, A2' and A9'. Occurrence of each variant was scored separately on the left and the right side of the skull.

Differences between samples were quantified using the Mean Measure of Divergence (MMD), which is the mean squared difference between frequencies of nonstandard traits (Sjøvold, 1977; Sikorski, 1982). Frequencies were first normalized using the angular transformation

$$
\Theta=\operatorname{Sin}^{-1}(1-2 p)
$$

where $\Theta$ is the transformed frequency $p$. MMD was then calculated as

$$
\text { MMD }=\frac{\sum\left(\Theta_{1}-\Theta_{2}\right)^{2}-V_{(1,2)}}{m},
$$

where $V_{(1,2)}$ is the variance of the estimate of the difference, which is calculated as

$$
V_{(1,2)}=\frac{1}{n_{1}+0.5}+\frac{1}{n_{2}+0.5},
$$

where $n$ is the sample size. Significance of MMD distances were determined using $V_{(1,2)}$. For $\alpha=0.05$, significant differences are those larger than 1.96 times the square root of $V_{(1,2)}$.

Asymmetry was estimated using two indices: (i) an index of fluctuating asymmetry (FA) as the variance of the difference between the right and left elements of a bilateral pair $(R-L)$ for a sample of individuals (Palmer $\&$ Strobeck, 1986), and (ii) the number of asymmetric traits per individual as an integrated measure of developmental stability (NA) (Leary et al., 1985; Zakharov, 1987). Differences in FA values among samples (whether the variances were homogeneous among groups) were estimated using Levene's test (Levene, 1960; see also Palmer \& Strobeck, 1986).

\section{Results}

Mean Measure of Divergence (MMD). Comparison between samples of adult and young shrews in the combined sample revealed significant differences $(\mathrm{MMD}=0.0376$, variance $=0.0002, p<0.05)$ so further analyses used young individuals only. There was signif-
Table 2. MMD values among samples of young shrews from different habitats.

\begin{tabular}{|l|c|c|c|}
\hline Samples (habitats) & MMD & Variance & $p$ \\
\hline Forest - sedge bog & 0.0426 & 0.0004 & $<0.05$ \\
\hline Forest - meadow & 0.0034 & 0.0003 & $\mathrm{~ns}$ \\
\hline Sedge bog - meadow & 0.0135 & 0.0001 & $\mathrm{~ns}$ \\
\hline
\end{tabular}

icant differentiation in MMD between samples from floodplain forest and sedge bog but no differences were found comparing samples from forest and meadow and those from sedge bog and meadow (Tab. 2).

Asymmetry. Statistically significant differences were found in the fluctuating asymmetry values (FA) between adult and young shrews, therefore adult individuals were excluded from further analyses. Furthermore, in a case of nine traits (A2, A2', A9, B5, B9, B11, B14, C2 and D4), sex-linked differences in FA were found and those traits were also excluded from further analyses.

Table 3. The values of fluctuating asymmetry (FA) and numbers of asymmetric traits per individual (NA) in samples of young common shrews from different habitats.

\begin{tabular}{|l|c|c|c|c|}
\hline \multirow{2}{*}{ Trait } & \multicolumn{3}{|c|}{ Habitat } & \multirow{2}{*}{} \\
\cline { 2 - 4 } & $\begin{array}{c}\text { Forest } \\
\mathrm{n}=27\end{array}$ & $\begin{array}{c}\text { Sedge bog } \\
\mathrm{n}=157\end{array}$ & $\begin{array}{c}\text { Meadow } \\
\mathrm{n}=39\end{array}$ & \\
\hline A1 & 0.00 & 0.06 & 0.03 & $\mathrm{~ns}$ \\
\hline A3 & 0.00 & 0.08 & 0.07 & $<0.01$ \\
\hline A4 & 0.00 & 0.01 & 0.00 & $\mathrm{~ns}$ \\
\hline A5 & 0.04 & 0.02 & 0.00 & $\mathrm{~ns}$ \\
\hline A8 & 0.00 & 0.01 & 0.05 & $<0.01$ \\
\hline A9' & 0.04 & 0.14 & 0.17 & $\mathrm{~ns}$ \\
\hline B1 & 0.24 & 0.26 & 0.28 & $\mathrm{~ns}$ \\
\hline B2 & 0.13 & 0.15 & 0.17 & $\mathrm{~ns}$ \\
\hline B3 & 0.04 & 0.05 & 0.05 & $\mathrm{~ns}$ \\
\hline B4 & 0.10 & 0.09 & 0.03 & $<0.05$ \\
\hline B6 & 0.00 & 0.01 & 0.03 & $\mathrm{~ns}$ \\
\hline B7 & 0.20 & 0.13 & 0.15 & $\mathrm{~ns}$ \\
\hline B8 & 0.04 & 0.09 & 0.09 & $\mathrm{~ns}$ \\
\hline B10 & 0.04 & 0.19 & 0.17 & $<0.05$ \\
\hline B12 & 0.23 & 0.32 & 0.29 & $\mathrm{~ns}$ \\
\hline C1 & 0.04 & 0.02 & 0.09 & $<0.01$ \\
\hline D1 & 0.48 & 0.21 & 0.23 & $<0.01$ \\
\hline D2 & 0.07 & 0.01 & 0.00 & $<0.01$ \\
\hline D3 & 0.10 & 0.19 & 0.23 & $\mathrm{~ns}$ \\
\hline D5 & 0.16 & 0.27 & 0.23 & $\mathrm{~ns}$ \\
\hline FA median & 0.04 & 0.09 & 0.09 & $<0.05$ \\
\hline NA & 2.19 & 2.59 & 2.79 & $<0.01$ \\
\hline
\end{tabular}

Differences in FA values among samples were compared using Levene's test (for heterogeneity of variances). Differences among FA medians and NA values were compared using $t$-tests. 
The FA values for seven traits $(\mathrm{A} 3, \mathrm{~A} 8, \mathrm{~B} 4, \mathrm{~B} 10$ $\mathrm{C} 1, \mathrm{D} 1$ and D2) differed significantly among samples of young shrews from different habitats (Tab. 3). There were differences in the FA medians in the samples. The value for the sample from forest was significantly lower than those for samples from sedge bog and meadow (Tab. 3). The numbers of asymmetric traits per individual (NA) were also different among samples. The lowest value was again in a case of the sample from forest but the highest one for the sample from meadow (Tab. 3).

\section{Discussion}

Patterns of epigenetic skeletal variation have often been considered to characterise the genetics of animal populations (e.g. Berry, 1963; Berry et al., 1978; Andersen \& Wiig, 1982; Sikorski, 1982; Hanski \& Kuitunen, 1986). In addition to the genetic component of epigenetic character regulation, environmental factors influence variation by decreasing developmental stability and hence increasing asymmetry. These factors include adverse temperatures, chemical pollutants, nutritional deprivations, high population density and audiogenic stress (Møller \& Swaddle, 1997) as well as diet and physiological state of the mother (Howe \& Parsons, 1967). Hartman (1980) and Hanski \& Kuitunen (1986) concluded that habitat effects (acting through individual size) influenced observed differences between localities in non-metric trait frequency and Pankakoski (1985) demonstrated that asymmetry in these traits was highly dependent on habitat quality.

Shrews are short-lived and do not move long distances, so their development can be expected to reflect local and transient environmental conditions (e.g. Pankakoski \& Hanski, 1989; Badyaev \& Foresman, 2000, 2004; Badyaev et al., 2000, 2005). In a cyclic population of the common shrew in Siberia, developmental stability, as measured by FA, was highly correlated with measures of habitat quality as population numbers waxed and waned (Zakharov et al., 1991). The evidence is convincing that greater levels of FA in shrews indicate more stressful environments.

Our results suggest that habitat quality affects nonmetric variation in Sorex araneus in Białowieża. We found significant MMD values between shrews sampled in floodplain forest and sedge bog habitats, suggesting genetic divergence between these two subpopulations. This is consistent with the earlier finding of Wójcik (1991) and Wójcik et al. (1996) of chromosome and allozyme polymorphisms whose frequencies differed between the same habitats that we studied. Together, these results indicate that there are genetic differences, probably arising through the action of selection rather than random processes. But, similar changes were not detected from mandible measurements (Wójcik et al., 2003). However, it is often assumed that populations differentiate at the chromosomal and biochemical levels before consistent mor- phological changes are detectable. The mandible especially is known to be slow to respond to genetic differentiation (Polly, 2007).

Most likely the MMD differences that we detected between habitats correspond to genetic differences in the subpopulations, but FA can affect MMD by elevating the variance in the expected values. In our study, the FA median value for the floodplain forest sample was significantly lower than those for the sedge bog and meadow samples. The total number of asymmetrical traits, NA, was also lowest in the forest sample and highest in the sample from meadow. This suggests that our MMD results are not biased by FA because the latter would increase spurious significant results in samples where it is higher. The floodplain forest and sedge bog samples were the most significantly different, yet they had the lowest asymmetry.

The FA results show that asymmetry is correlated with the quality of each habitat for common shrews. Forest and sedge bog are better biotopes for shrews than meadows. Both the frequency and number of asymmetrical traits were lowest in the desirable forest habitat. FA was equal in sedge bog and meadow, but NA was highest in meadow habitat. This pattern is consistent with forest habitat being optimal for Sorex araneus at Białowieża, and meadow habitat being suboptimal.

The distance between our habitat samples was very small and no obvious physical or environmental barriers exist between them. We presume that shrews could move easily between study plots, and it is known that they are capable of dispersing quite widely (e.g. Hanski $\&$ Kaikusalo, 1989). Therefore, the differences in epigenetic variation found in this study cannot be only considered as a direct selective effect of the environmental heterogeneity. Other factors than ecological adaptations probably play an important role in the shrew population in Białowieża. For instance, differences may be a consequence of the competition between shrews for "good territories" in different habitats. The "stronger" individuals may try to establish their territories in the forest and bog habitats, while "weaker" shrews might be driven off to less attractive dry meadows. This sorting may result in genetic differentiation if competitive fitness is heritable (less fit meadow shrews would have less fit offspring, which are confined by competition to the suboptimal dry meadow habitats), but it will certainly result in sorting of animals of different fitness by habitat. The combination of low individual fitness and a more stressful environment are likely to be the cause of the greater non-metric asymmetry in the meadow habitats.

Why are meadows suboptimal for Sorex araneus? Badyaev \& Foresman (2000, 2004), and Badyaev et al. $(2000,2005)$ found a strong increase in asymmetry in shrews born in habitats suffering vegetation removal. Our results are consistent with their findings: open habitats such as sedge bog and meadow are more stressful for shrews because of factors like predation susceptibility and prey availability. 


\section{Conclusion}

We found that epigenetic differentiation among common shrews, Sorex araneus, was related to environmental heterogeneity. Frequencies of non-metric traits were significantly different between floodplain forest and sedge bog habitats, probably corresponding to genetic differentiation between subpopulations in these areas as suggested by previous analyses of karyotype and allozyme polymorphisms. The amount of asymmetry was highest in meadow habitats, apparently associated with this habitat being suboptimal for shrews. The pattern of epigenetic variation combined with previous studies of allozymes, chromosome polymorphism and mandibular shape suggest that competitive interactions associated with habitat preference can drive genetic differentiation in Sorex araneus.

ACKNOWLEDGMENTS. This study was supported through the BIOTER Centre of Excellence in Biodiversity Conservation and Mammal Research in European Terrestrial Ecosystems grant from the European Commission's Fifth Framework Programme (Contract EVK2-CT-2002-80011) and grant No. 6-6012-92-03 from the State Committee for Scientific Research in Poland.

\section{References}

Andersen T. \& Wiig O. 1982. Epigenetic variation in a fluctuating population of lemming (Lemmus lemmus) in Norway // Journal of Zoology. Vol.197. P.391-404.

Badyaev A.V., Foresman K.R. \& Fernandes M.V. 2000. Stress and developmental stability: vegetation removal causes increased fluctuating asymmetry in shrews // Ecology. Vol.81. P.336-345.

Badyaev A.V. \& Foresman K.R. 2000. Extreme environmental change and evolution: stress-induced morphological variation is strongly concordant with patterns of evolutionary divergence in shrew mandibles // Proceedings of the Royal Society of London. Series B. Vol.267. P.371-377.

Badyaev A.V. \& Foresman K.R. 2004. Evolution of morphological integration. I. Functional units channel stressinduced variation in shrew mandibles // American Naturalist. Vol.163. P.868-879.

Badyaev A.V., Foresman K.R. \& Young R.L. 2005. Evolution of morphological integration: developmental accommodation of stress-induced variation // American Naturalist. Vol.166. P.382-395.

Berry R.J. 1963. Epigenetic polymorphism in wild population of Mus musculus // Genetical Research. Vol.4. P.193220.

Berry R.J. \& Searle A.G. 1963. Epigenetic polymorphism on the rodent skeleton // Proceedings of the Zoological Society of London. Vol.140. P.577-615.

Berry R.J., Jakobson M.E. \& Peters J. 1978. The house mice of the Faroe Islands: a study in microdifferentiation // Journal of Zoology. Vol.185. P.73-92.

Foresman K.R. 1994. Comparative embryonic development of the Soricidae // Merritt J.F., Kirkland G.L.J. \& Rose
R.K. (eds.). Advances in the Biology of Shrews. Pittsburgh: Carnegie Museum of National History. P.241258.

Genoud M. 1988. Energetic strategies of shrews: ecological constraints and evolutionary implications // Mammal Review. Vol.18. P.173-193.

Hanski I. 1986. Population dynamics of shrews on small islands accord with the equilibrium model // Biological Journal of the Linnean Society. Vol.28. P.23-36.

Hanski I. \& Kaikusalo A. 1989. Distribution and habitat selection of shrews in Finland // Annales Zoologici Fennici. Vol.26. P.339-348.

Hanski I. \& Kuitunen J. 1986. Shrews on small islands: epigenetic variation elucidates population stability // Holarctic Ecology. Vol.9. P.193-204.

Hartman S.E. 1980. Geographical variation analysis of $D i$ podomys ordii using nonmetric cranial traits // Journal of Mammalogy. Vol.61. P.436-448.

Hausser J. \& Jammot D. 1974. Etude biométrique des mâchoires chez les Sorex du groupe araneus en Europe continentale (Mammalia, Insectivora) // Mammalia. Vol.38. P.324-343.

Howe W.L. \& Parsons P.A. 1967. Genotype and environment in the determination of minor skeletal variants and body weight in mice // Journal of Embryology and Experimental Morphology. Vol.17. P.285-292.

Leary R.F. \& Allendorf F.W. 1989. Fluctuating asymmetry as an indicator of stress: Implications for conservation biology // Trends in Ecology \& Evolution. Vol.4. P.214217.

Leary R.F., Allendorf F.W., Knudson R.L. \& Thorgaard G.H. 1985. Heterozygosity and developmental stability in gynogenetic diploid and triploid rainbow trout // Heredity. Vol.54. P.219-225.

Levene H. 1960. Robust tests for equality of variances // Olkin I. (ed.). Contributions to Probability and Statistics. Stanford: Stanford University Press. P.278-292.

Meyer A. \& Searle J.B. 1994. Morphological studies on British common shrews // Folia Zoologica. Vol.43. Suppl.1. P.115.

Møller A.P. \& Swaddle J.P. 1997. Asymmetry, Developmental Stability, and Evolution. Oxford: Oxford University Press.

Palmer A. R. \& Strobeck C. 1986. Fluctuating asymmetry: measurement, analysis, patterns // Annual Review of Ecology and Systematics. Vol.17. P.391-421.

Palmer A.R. \& Strobeck C. 1992: Fluctuating asymmetry as a measure of developmental stability: Implications of non-normal distributions and power of statistical tests // Acta Zoologica Fennica. Vol.191. P.57-72.

Pankakoski E. \& Hanski I. 1989. Metrical and non-metrical skull traits of the common shrew Sorex araneus and their use in population studies // Annales Zoologici Fennici. Vol.26. P.433-444.

Pankakoski E., Koivisto I. \& Hyvarinen H. 1992. Reduced developmental stability as an indicator of heavy metal pollution in the common shrew Sorex araneus // Acta Zoologica Fennica. Vol.191. P.137-144.

Pankakoski E. 1985. Epigenetic asymmetry as an ecological indicator in muskrats // Journal of Mammalogy. Vol.66. 
P.52-57.

Polly P.D. 2007. Phylogeographic differentiation in Sorex araneus: morphology in relation to geography and karyotype // Russian Journal of Theriology. Vol.6. No.1. P.73-84.

Sikorski M.D. 1982. Non-metrical divergence of isolated populations of Apodemus agrarius in urban areas // Acta Theriologica. Vol.27. P.169-180.

Sjøvold T. 1977. Non-metrical divergence between skeletal populations // Ossa. Vol.4. Suppl.1. P.1-133.

Wójcik J.M. 1991. Chromosomal polymorphism in the common shrew Sorex araneus and its adaptive singnificance // Mémoires de la Société vaudoise des Sciences naturelles. Vol.19. P.51-62.

Wójcik J.M., Wójcik A.M. \& Zalewska H. 1996. Chromosome and allozyme variation of the common shrew, Sorex araneus, in different habitats // Hereditas. Vol.125. P.183-189.

Wójcik J.M., Wójcik A.M. \& Sikorski M.D. 2003. Morphometric variation of the common shrew, Sorex araneus, in different habitats // Mammalia. Vol.67. P.225-231.
Zakharov V.M. 1987. [Asymmetry of Animals]. Moskva: Nauka [in Russian].

Zakharov V.M. 1992. Population phenogenetics: analysis of developmental stability in natural populations // Acta Zoologica Fennica. Vol.191. P.7-30.

Zakharov V.M., Demin D.V., Baranov A.S., Borisov V.I., Valetsky A.V. \& Sheftel B.I. 1997a. Developmental stability and population dynamics of shrews Sorex in central Siberia // Acta Theriologica. Suppl.4. P.41-48.

Zakharov V.M., Pankakoski E. \& Sheftel B.I. 1997b. Phenotypic diversity and population dynamics: another look (with particular reference to the common shrew Sorex araneus) // Acta Theriologica. Suppl.4. P.57-66.

Zakharov V.M., Pankakoski E., Sheftel B.I., Peltonen A. \& Hanski I. 1991. Developmental stability and population dynamics in the common shrew, Sorex araneus // American Naturalist. Vol.138. P.797-810.

Zima J., Fedyk S., Fredga K., Hausser J., Mishta A., Searle J.B., Volobouev V.T. \& Wójcik J.M. 1996. The list of the chromosome races of the common shrew (Sorex araneus) // Hereditas. Vol.125. P.97-107. 